Special Issue Nr. 43: Advertising Literacy. How Can Children and Adolescents Deal with Persuasive Messages in a Complex Media Environment?

Edited by Brigitte Naderer, Nils S. Borchers, Ruth Wendt and Thorsten Naab

\title{
A Path Toward a More Understandable Advertising Disclosure for Children
}

\section{Conceptualizing Determining Factors for Disclosure Effectiveness and Opportunities for Future Research}

Ines Spielvogel (D)

\begin{abstract}
Children are heavily confronted with advertising messages in their media environments. Given the emotional nature of contemporary advertising and children's still developing cognitive skills, young consumers are hardly able to cope critically with advertising attempts. So that children are able to detect the persuasive intent, advertising disclosures are viewed as potential supportive measures to mitigate harm that excessive advertising might cause to children. However, the effects of advertising disclosures on children's awareness of persuasion, i.e., "persuasion knowledge," appear to be mixed. Moreover, scholars of this research field lack a consensus about what kind of determining factors play important roles in terms of children's persuasion knowledge activation through disclosures. The present study builds on persuasion knowledge literature and investigates whether the factors identified in this research field can be also transferred to advertising disclosures. The results of a literature review of previous disclosure research show that disclosures might need specific 'features' so that advertising disclosures can be effective among children. Furthermore, not all children appear to be equally likely to grasp the meaning of disclosures. However, individual factors other than age might be more important in this context, including environment and situation. Finally, opportunities for future research are discussed.
\end{abstract}

Wege zu einem verständlicheren, werbebezogenen Aufklärungshinweis bei Kindern. Eine Konzeptualisierung der ausschlaggebenden Faktoren für die Effektivität von Aufklärungshinweisen und Möglichkeiten für zukünftige Forschung

\footnotetext{
Zusammenfassung

Kinder sind in ihrer Medienumgebung einer Vielzahl von Werbebotschaften ausgesetzt. Insbesondere Kindern fällt es aufgrund des starken emotionalen Charakters von gegenwärtiger Werbung und den sich noch entwickelnden kognitiven Fähigkeiten schwer, Persuasionsversuche kritisch zu verarbeiten. Werbebezogene Aufklärungshinweise werden
} 
in diesem Zusammenhang als potenzielle unterstützende Maßnahmen angesehen, damit Kinder die persuasive Absicht von Werbung besser erkennen können. Die Ergebnisse zu den Auswirkungen von diesen Hinweisen auf das kindliche Persuasionswissen sind jedoch nicht eindeutig. Darüber hinaus benötigen Wissenschaftlerinnen und Wissenschaftler in diesem Forschungsbereich einen präzisen Überblick darüber, welche Faktoren für die Aktivierung des kindlichen Persuasionswissens durch Hinweise ausschlaggebend sind. Die vorliegende Studie baut auf der Literatur über das Persuasionswissen auf und untersucht, ob sich die Faktoren, die in diesem Forschungsbereich identifiziert wurden, auch auf werbebezogene Aufklärungshinweise übertragen lassen. Die Ergebnisse einer Literaturrecherche von bestehenden Aufklärungshinweis-Studien weisen darauf hin, dass werbebezogene Aufklärungshinweise besondere «Merkmale erfordern, damit diese bei Kindern auch effektiv sind. Außerdem kann angenommen werden, dass nicht alle Kinder die Bedeutung der Hinweise gleichermaßen verstehen. In diesem Zusammenhang könnten jedoch andere individuelle Faktoren als das Alter ausschlaggebend sein. Die vorgeschlagene Konzeptualisierung identifiziert auch die Umwelt und die Situation als mögliche relevante Faktoren für die Wirksamkeit von werbebezogenen Aufklärungshinweisen bei Kindern. Denkbare zukünftige Forschungsbereiche werden diskutiert.

\section{Introduction}

In recent years, the young consumer's advertising landscape has changed immensely. Children today encounter advertising messages in various formats, including print advertising, commercial breaks on television, product placements within television programs, sponsored content by influencers on social media, or advergames on online websites (Rideout 2014). Especially in the case of embedded advertising formats like product placement or influencer marketing, it is hard for children to react appropriately to the persuasive content. Children, and adults, can have a hard time processing these messages on an elaborate level and even detecting the persuasive intent due to its hidden, emotion-based nature (Buijzen, van Reijmersdal, and Owen 2010; Nairn and Fine 2008; Rozendaal et al. 2011). Policy makers, consumer advocates, and parents are therefore concerned that embedded advertising targeted at children may result in an increased risk of undesired consequences such as parentchild conflicts, materialistic attitudes, and/or childhood obesity (Cain Reid 2014; Hudson, Hudson, and Peloza 2008). Against this background, a myriad of studies has revealed that exposure to persuasive messages embedded in entertainment media content can elicit unhealthy eating behaviors in children among other undesirable effects (e.g., Auty and Lewis 2004; Brown et al. 2017; Folkvord et al. 2015; Naderer et al. 2018).

In the context of unintended advertising effects on children, advertising disclosures (e.g., 'this program contains advertising') are viewed as potential supportive measures (De Jans et al. 2019; Hudders et al. 2017). In the last decade, scholars have 
thus increasingly investigated whether advertising disclosures can help children to cope critically with advertising attempts by activating their persuasion knowledge (De Jans et al. 2019). However, based on the findings of De Jans et al. (2019), who comprehensively reviewed advertising papers from 2006 to 2016, advertising disclosures' effects on children's knowledge of persuasion appear to be mixed. Despite this finding, current research on persuasion knowledge still lacks a systematic literature review that focuses on advertising disclosures' effects on children (Boerman and van Reijmersdal 2016). Additionally, we lack knowledge about what kind of determining factors have been covered by previous research and which of these factors play important roles in terms of persuasion knowledge activation and which do not.

Several studies with adult subjects emphasize that disclosure awareness measured through disclosure recall or recognition constitute preconditions that allow an advertising disclosure to have its intended effect on the activation of persuasion knowledge (Boerman, van Reijmersdal, and Neijens 2012; Boerman, van Reijmersdal, and Neijens 2015a; 2015b). There are also initial results about the necessity of this precondition in the case of children (Boerman and van Reijmersdal 2020; van Reijmersdal et al. 2017). As previous literature suggests, however, adults have a higher capacity to process persuasive messages in a more systematic manner than children do (Buijzen, van Reijmersdal, and Owen 2010). This indicates that the presentation of the disclosure might need special 'features' to effectively communicate their message and be recognized by children. Against this background, current research reveals that compared to disclosures used in practice, disclosures more appropriate for children (e.g., through the use of flashy colors and specific wording) not only increased children's disclosure recognition, but also their understanding and liking of these cues (De Jans et al. 2018). The latest results on disclosures shown on audiovisual media targeted at all ages, however, indicate that disclosures used in practice are rather small, rarely consist of flashy colors and for the most part only contain a symbol with no further explanation (Spielvogel, Naderer, and Matthes 2021). Similar findings were found in the case of advergames targeted at children (An and Kang 2013).

Furthermore, children may not all be equally likely to grasp the meaning of disclosures. We therefore need to conceptualize which additional corresponding factors may be important to use in this context according to what has already been identified by previous research in this field. In order to do so, we can build on persuasion knowledge literature and investigate whether factors identified in this field can also be transferred to advertising disclosures.

When children are the audience, environmental factors (e.g., family environment) are considered to play an important role on advertising effects (Hudders and Cauberghe 2018). This circumstance might also be an issue for advertising disclosure effectiveness. Furthermore, situational factors (e.g., involvement with the media 
content) can influence children's brand responses (van Reijmersdal, Rozendaal, and Buijzen 2012), which may also be true when considering how children respond to advertising disclosures. When following persuasion knowledge literature, environmental and situational factors not only explain advertising effects but also how children's knowledge of persuasion is acquired and amassed (Nelson et al. 2017; Terlutter and Spielvogel 2010; Zarouali et al. 2019b).

There remains a special need to determine under which circumstances children are more able to activate their knowledge of persuasion when being exposed to advertising disclosures. Furthermore, revealing under which circumstances children remember disclosures at their best is of great importance. In short, it is imperative to specify the determining factors responsible for advertising disclosure effectiveness. The present study aims to conceptualize a path toward more understandable advertising disclosures for children. This conceptualization will be methodically achieved through a literature review.

\section{Theoretical Background}

\subsection{Defining Persuasion Knowledge and the Dimensions Thereof}

According to Friestad and Wright's (1994) Persuasion Knowledge Model (PKM) persuasion knowledge refers to consumers' general knowledge and beliefs about persuasion, which also includes advertising-related issues. It further relates to consumers' ability to automatically retrieve and activate this knowledge. The PKM furthermore argues that on the basis of vast practical experiences that consumers gain with persuasive attempts, everyday knowledge of persuasion gradually develops over a lifetime (Friestad and Wright 1994; Wright, Friestad, and Boush 2005). In other words, our knowledge and beliefs about persuasion get more sophisticated and nuanced over time. In their theoretical essay on children's advertising processing, Rozendaal et al. (2011) emphasize that this knowledge incorporates both a cognitive and affective dimension (for this distinction see also e.g., van Rejmersdal et al. 2017).

Conceptual persuasion knowledge represents the cognitive dimension and can be defined as individuals' basic understanding of persuasive attempts, including embedded advertising messages (Boerman et al. 2018; Rozendaal et al. 2011). Based on various theoretical models of the child development and advertising literature (for an overview, see Wright, Friestad, and Boush 2005), this dimension includes several components, such as consumer's recognition of advertising, understanding of the source, understanding of the commercial and persuasive intent, and/or understanding of persuasive tactics (Rozendaal et al. 2011; Zarouali et al. 2019b). In more recent literature, "conceptual advertising literacy" (e.g., van Dam and van Reijmersdal 
2019) or "cognitive advertising literacy" (e.g., De Pauw, Hudders, and Cauberghe 2018; Zarouali et al. 2019a) heavily build upon the axioms of the PKM (Friestad and Wright 1994). In other words, these different terms are both at the heart of the same theoretical considerations and are operationalized by at least one of the theorized components of conceptual persuasion knowledge. Compared to persuasion knowledge, advertising literacy refers to advertising attempts in particular and thus excludes other sources of persuasion (De Jans et al. 2019; Zarouali et al. 2019a; 2019b).

Attitudinal persuasion knowledge, in contrast, represents the affective dimension of persuasion knowledge as represented by its two most important components: skeptical thoughts about advertising and general negative attitudes toward advertising (Boerman et al. 2012; 2018; Rozendaal et al. 2011). This, for instance, involves critical feelings toward advertising about the company's honesty, credibility, or trustworthiness (Boerman et al. 2018). Current research has also added an ethical component that refers to moral facets related to advertising, such as reflections on the appropriateness of advertising (Hudders et al. 2017). In the most recent literature, attitudinal persuasion knowledge can almost be equated with "attitudinal advertising literacy" (e.g., Hoek et al. 2020), "affective advertising literacy" (e.g., De Jans, Cauberghe, and Hudders 2018; Zarouali et al. 2019a), or "evaluative persuasion knowledge" (Boerman et al. 2018). Again, these different terms refer to the same theoretical foundations.

Several scholars in this field build on the idea of a two-dimensional persuasion knowledge for two reasons: First, the cognitive conceptualization of conceptual persuasion knowledge alone is inadequate to illustrate the emotion-based nature of contemporary advertising targeted at children (Rozendaal et al. 2011; Hudders et al. 2016). Second, due to children's nascent cognitive processing skills, young consumers are less likely to engage in a systematic persuasion process, which reduces the likelihood that their conceptual advertising knowledge is activated (Buijzen, van Reijmersdal, and Owen 2010).

Furthermore, advertising research indicates that consumers' critical feelings toward the advertised content (i.e., attitudinal persuasion knowledge) can be activated once the conceptual dimension is triggered (Boerman et al. 2012; Boerman and van Reijmersdal 2016). This assumption is based on the "change of meaning" principle of the PKM (Friestad and Wright 1994). When consumers realize that marketers are trying to persuade them, they will disengage from the attempt. According to the PKM, this process is defined as "detachment" (Friestad and Wright 1994). On this basis, it is further assumed that consequences of persuasion knowledge activation can also be transferred to the brand, and in children this can lead to changes to brand evaluation and/or the purchase intention of the advertised brand (Rozendaal, Buijs, and van Reijmersdal 2016; van Reijmersdal and van Dam 2020). 


\subsection{Determining Factors for the Development of Children's Persuasion Knowledge}

The body of research of the last several decades indicates that various factors are responsible for the development of children's persuasion knowledge. From a theoretical perspective, persuasion knowledge predominantly depends on the growth of social and cognitive abilities in consumers as well as socialization processes. This circumstance is theoretically known as consumer socialization (Buijzen, van Reijmersdal, and Owen 2010; Hudders et al. 2017; John 1999). This subchapter introduces the most important determining factors of the development of children's advertising skills as identified by foundational and more recent studies. These factors are sorted according to individual, environmental, and situational factors.

\section{Individual Factors}

The investigation of the relationship between children's persuasion knowledge and their age is well-established and represents the heart of most research in this field (John 1999; Lapierre 2015; Terlutter and Spielvogel 2010). When explaining the progressive understanding of advertising based on age-based changes, the vast majority of previous studies build on the foundational theories of Piaget's model of cognitive development (Piaget 1929). These theoretical insights are also included in the model of young people's processing of commercialized media content (PCMC) developed by the authors Buijzen et al. (2010). Their model delineates four phases in the development of children's persuasion processing: 1 ) early childhood (up to 5 years old), 2) middle childhood (6 to 9 years old), 3) late childhood (10 to 12 years old), and 4) adolescence (older than 12 years). It is assumed that within each phase, children acquire advertising-related cognitive skills and social experience until children reach an adult-like level of these competences at the approximate age of 16 (Buijzen, van Reijmersdal, and Owen 2010; John 1999). In short, research presumes that with increasing age, individuals' knowledge of persuasion also increases.

Over the past several decades, many studies have indicated that individuals' knowledge of persuasive communication strongly correlates with their age (see e.g., John 1999). In this light, the authors Terlutter and Spielvogel (2010) also review research on influential factors for the development of children's advertising awareness skills. Their findings showed that all the included studies that deal with age have shown a positive correlation with the achievement of advertising skills. For the most part, however, these studies concentrate on traditional advertising. When it comes to contemporary advertising formats such as product placements, existing studies indicate that children gain an understanding of these embedded persuasive messages around the age of 10 (e.g., Grohs et al. 2015).

Beside this 'immutable' supporting construct, previous studies identify further individual factors that might be also responsible for persuasion-knowledge development in children. More specifically, it has been asserted that scholars in this research area predominantly use age as a proxy indicator although persuasion knowledge has 
been framed as a cognitive skill (Lapierre 2015). Other researchers thus investigate specific cognitive competencies (hereafter defined as 'mutable' supporting constructs).

For instance, it was shown that the linguistic competence of a child serves as a driving force for persuasion understanding, even when controlling for children's age (Chernin 2007). Furthermore, Lapierre (2015) found that children who performed better on measures of Theory of Mind (TOM) were more likely to understand the advertisers' selling intent (but not its persuasive intent). Children with higher ToM scores had a greater knowledge of the "beliefs about someone else's mental state" (first-order beliefs) and of the "beliefs about someone else's mental state regarding another person's mental state" (second-order beliefs; ibid. 427). Other scholars also explain a delayed advertising understanding (assessed by increasing age) in part by the development of executive function skills (Rozendaal et al. 2011). In the case of more highly developed executive function, children are more able to inhibit attention paid to salient perceptual cues of advertising targeted at children and affective responses to advertising.

\section{Environmental and Situational Factors}

Although children's individual factors have been a focus in the research of predicting the development of persuasive understanding, environmental factors have also been a subject of research. The literature review of Terlutter and Spielvogel (2010) on influential factors for children's advertising skills concludes that there is also a strong influence of children's family environment. This includes the broad social environment that is primarily determined by social affiliation and personal relationships between parents and children, which are predominantly shaped by the level of education of the parents and the parenting style.

A recently published study with a focus on contemporary advertising formats also shows that children's environments significantly affect their ability to cope with embedded persuasive attempts (De Pauw, Cauberghe, and Hudders 2018). In their study, peers were most influential in terms of children's conceptual and attitudinal persuasion knowledge. However, especially in the case of younger children, parents are important social agents who positively influence the development of children's persuasion knowledge through educating them about the function of advertising (Zarouali et al. 2019b). In this light, the latest published studies devote special attention to the connection between parental advertising mediation and children's persuasion knowledge (De Jans et al. 2019; Hudders and Cauberghe 2018).

Another important environmental factor constitutes the media itself (Nelson et al. 2017). Several studies about the field of advertising therefore investigated whether and how different advertising types and characteristics affect children's knowledge of persuasion. For instance, a recently published study showed that children's subsequent understanding of persuasive intent was higher for personalized social media 
advertising than for non-personalized ads (Daems et al. 2019). However, the investigation of how children respond to embedded advertising formats such as vlog advertising is still in its infancy (De Jans et al. 2019). In general, it is assumed that children's knowledge of understanding for contemporary advertising formats tends to be lower than for traditional formats due to its subtle nature (Verhellen et al. 2014).

Furthermore, recent studies examine how situational factors influence children's persuasion knowledge. However, to my knowledge, such studies with children are quite rare when compared to other investigated factors. A study on advergaming and children's persuasion knowledge found that game-related variables such as children's experience of game flow was positively associated with their level of persuasion knowledge (Vanwesenbeeck, Ponnet, and Walrave 2016). More specifically, children who reported being totally absorbed in the game simultaneously reported greater knowledge of the game's selling and persuasive intent. With regard to formats other than advergaming where children experience an intense state of complete immersion, involvement with media content might be a more appropriate variable (van Reijmersdal, Rozendaal, and Buijzen 2012).

Given this overview, it becomes apparent that various factors are responsible for the development of children's persuasion knowledge. However, overall the current literature on children's persuasion processing suggests that even if children possess persuasion knowledge, they may fail to activate this knowledge while processing advertising messages (Buijzen, van Reijmersdal, and Owen 2010; John 1999; Rozendaal et al. 2011). Thus, even if specific individual, environmental, or situational factors might support the development of persuasive understanding in children, this does not automatically mean that children's knowledge is activated when they are exposed to advertising messages.

In their theoretical essay, Rozendaal et al. (2011) therefore call for a stronger emphasis on the distinction between dispositional and situational persuasion knowledge (referred to as "advertising literacy performance"). In the context of advertising, dispositional persuasion knowledge "can be perceived as an associative network of information nodes related to advertising" (De Jans, Hudders, and Cauberghe 2018, 403). Situational persuasion knowledge, in contrast, refers to consumers' coping with the embedded persuasion tactic through knowledge activation (De Jans, Hudders, and Cauberghe 2018; Ham, Nelson, and Das 2015).

\subsection{Improving Children's Persuasion Knowledge Activation Through Advertising}

\section{Disclosures}

According to Friestad and Wright's (1994) PKM, consumers can only activate their persuasion knowledge if they recognize a persuasion attempt. Against this background, it is presumed that advertising disclosures (e.g., "this program contains 
advertising") can trigger persuasion knowledge and prevent consumers from being subconsciously persuaded since the disclosure helps them to recognize advertising (De Jans et al. 2019).

Several scholars thus argue that children need to be cued about the upcoming advertising content (De Jans et al. 2018; De Pauw, Hudders, and Cauberghe 2018; Hudders et al. 2017). Compared to adults, children's cognitive skills are limited, which makes it even harder for them to process embedded advertising formats in a systematic manner (Buijzen, van Reijmersdal, and Owen 2010). Hence, the examination of how advertising disclosures affect children has become increasingly popular among scholars (De Jans et al. 2019). The latest research even seeks to determine and provide disclosures that are more suitable for children (De Jans et al. 2018). However, based on the findings of the authors De Jans et al. (2019), who comprehensively reviewed advertising papers from 2006 to 2016, advertising disclosures' effects on children's persuasion knowledge appear to be mixed. Despite this assumption, the current research in this area still lacks a systematic review that focuses on advertising disclosures' effects on persuasion knowledge in connection with children (Boerman and van Reijmersdal 2016).

RQ1: What are the potential effects of advertising disclosures on children's persuasion knowledge?

Additionally, scholars in this particular field lack a concise overview about which determining factors play important roles in terms of persuasion knowledge activation and which do not. Hence, one key aim of the present study is to define all the determining factors that have been identified by previous experimental research in the context of advertising disclosures and children's persuasion knowledge. Furthermore, the present study aims to identify additional factors that might be important in this context. In order to do so, we can build on the persuasion-knowledge literature and investigate whether factors identified in this research field can also be transferred to advertising disclosures.

RQ2: a) What determining factors have been covered by previous advertising disclosure research on children and their persuasion knowledge,

and b) what additional factors might be important in this context?

Although brand-related changes (e.g., brand evaluation, purchase intention of the advertised brand, etc.) can be the consequence of persuasion-knowledge activation, these changes are not at the heart of the aim of advertising disclosures because "whatever the form, the purpose of the disclosure is 1 ) to help children recognize the commercial content and 2) to disclose its persuasive intent." (Hudders et al. 2017, 346) Disclosure effects on persuasion outcomes are thus not the main object of the research of the present study. 


\section{Method}

\subsection{Research Process}

In order to answer the research questions, a literature review1 was conducted. I performed an exhaustive search of published or accepted empirical studies that refer to advertising disclosures in connection with children and adolescents. I identified relevant studies by first referring to a review on advertising papers that included disclosure studies from 2011 to 2016 in connection with children (De Jans et al. 2019). Second, I performed a keyword search of electronic databases including ResearchGate and Google Scholar. I used specific keywords to identify literature that specifically focuses on children and adolescents (e.g., "adverting disclosures children"). Last, I reviewed the references listed in each paper.

Initially, a total sample of $N=22$ studies was identified through this research process. However, some studies referring to advertising disclosures targeted at children actually investigate their influence on parents rather than children (Evans and Hoy 2016; Evans, Hoy, and Childers 2018). These studies were excluded from the sample. Furthermore, studies that do not test disclosure effects but instead focus on the appreciation of advertising disclosures were also excluded (van Dam and van Reijmersdal 2019). This procedure led to $N=19$ studies being included. The sample size is comparable to similar analyses that have been done in this research area among adults (Boerman and van Reijmersdal 2016).

\subsection{Sample Characteristics}

The sampled studies focus on various advertising formats including social media advertising $(n=8)$, product placements in television programs $(n=5)$, online website advertising $(n=5)$, traditional television advertising $(n=3)$, and print advertising ( $n$ $=1$ ). The included studies also address different developmental stages. The investigated children of these studies had a minimum age of five and a maximum age of seventeen, and the greater part of the sampled studies included children in the age range of nine to eleven years old. Table 1 offers an overview of the included studies.

1 Note: The literature review was concluded in June 2020 and updated during a revision process in October 2020. 


\begin{tabular}{|c|c|c|c|c|c|c|c|}
\hline $\mathrm{Nr}$. & $\begin{array}{l}\text { Advertising } \\
\text { Type }\end{array}$ & $\begin{array}{l}\text { Stage of } \\
\text { Devel- } \\
\text { opment }\end{array}$ & $\begin{array}{l}\text { Independent } \\
\text { Variable(s) }\end{array}$ & Mediator(s) & Moderator(s) & $\begin{array}{l}\text { Dependent } \\
\text { Variable(s) }\end{array}$ & $\begin{array}{l}\text { Effects of Advertising Disclo- } \\
\text { sures on } \mathrm{PK}^{\star}\end{array}$ \\
\hline \multirow[t]{2}{*}{1} & \multirow[t]{2}{*}{ Advergames } & \multirow[t]{2}{*}{$\begin{array}{l}8 \text { to } 11 \\
\text { years }\end{array}$} & $\begin{array}{l}\text { Presence of a } \\
\text { disclosure (no } \\
\text { disclosure vs. } \\
\text { disclosure) }\end{array}$ & - & - & $\begin{array}{l}\text { Conceptual PK } \\
\text { (understanding } \\
\text { of persuasive } \\
\text { intent, detec- } \\
\text { tion of per- } \\
\text { suasive agent) } \\
\text { / Brand out- } \\
\text { comes (recall, } \\
\text { preference) }\end{array}$ & $\begin{array}{l}\text { - No main effect of use of dis- } \\
\text { closures on understanding of } \\
\text { persuasive intent } \\
\text { - No main effect of use of disclo- } \\
\text { sures on detection of persuasive } \\
\text { agent }\end{array}$ \\
\hline & & & $\begin{array}{l}\text { Disclosure } \\
\text { modality (visual } \\
\text { vs. auditory } \\
\text { vs. combined } \\
\text { disclosure) }\end{array}$ & - & - & $\begin{array}{l}\text { Conceptual } \\
\text { PK (measures } \\
\text { as in model 1) } \\
\text { / Brand out- } \\
\text { comes (recall, } \\
\text { preference) }\end{array}$ & $\begin{array}{l}\text { - No main effect of disclosure } \\
\text { condition on conceptual PK (no } \\
\text { differences between visual and } \\
\text { auditory disclosure) } \\
\text { - No positive main effect of com- } \\
\text { bined version (compared to } \\
\text { visual and auditory disclosure) }\end{array}$ \\
\hline 2 & $\begin{array}{l}\text { Sponsored } \\
\text { influencer } \\
\text { videos }\end{array}$ & $\begin{array}{l}8 \text { to } 12 \\
\text { years }\end{array}$ & $\begin{array}{l}\text { Presence of a } \\
\text { disclosure (no } \\
\text { disclosure vs. } \\
\text { disclosure) }\end{array}$ & $\begin{array}{l}\text { Conceptual PK } \\
\text { (advertising } \\
\text { recognition, } \\
\text { understand- } \\
\text { ing of selling } \\
\text { intent, and } \\
\text { understanding } \\
\text { of persuasive } \\
\text { intent) }\end{array}$ & $\begin{array}{l}\text { Para-social } \\
\text { relationship }\end{array}$ & $\begin{array}{l}\text { Brand out- } \\
\text { comes (recall, } \\
\text { attitude desire) }\end{array}$ & $\begin{array}{l}\text { - Positive main effects of the } \\
\text { use of disclosures on all com- } \\
\text { ponents of conceptual PK } \\
\text { (but only among children who } \\
\text { correctly recalled seeing the } \\
\text { disclosure) }\end{array}$ \\
\hline 3 & $\begin{array}{l}\text { Sponsored } \\
\text { influencer } \\
\text { videos }\end{array}$ & $\begin{array}{l}9 \text { to } 11 \\
\text { years }\end{array}$ & $\begin{array}{l}\text { Branded food } \\
\text { product: } \\
\text { Presence of a } \\
\text { disclosure (no } \\
\text { disclosure vs. } \\
\text { disclosure); } \\
\text { control group: } \\
\text { Influencer } \\
\text { marketing of } \\
\text { a non-food } \\
\text { product }\end{array}$ & - & - & $\begin{array}{l}\text { Caloric intake } \\
\text { of marketed } \\
\text { snack }\end{array}$ & - \\
\hline 4 & $\begin{array}{l}\text { Personal- } \\
\text { ized social } \\
\text { media ad- } \\
\text { vertising }\end{array}$ & $\begin{array}{l}9 \text { to } 13 \\
\text { years }\end{array}$ & $\begin{array}{l}\text { Advertising } \\
\text { type (personal- } \\
\text { ized vs. non- } \\
\text { personalized) }\end{array}$ & $\begin{array}{l}\text { Conceptual PK } \\
\text { (understanding } \\
\text { of selling in- } \\
\text { tent) / Attitude } \\
\text { toward adver- } \\
\text { tising / }\end{array}$ & $\begin{array}{l}\text { Presence of a } \\
\text { disclosure (no } \\
\text { disclosure vs. } \\
\text { disclosure) }\end{array}$ & WOM intention & $\begin{array}{l}\text { - The use of disclosures moder- } \\
\text { ates the effect of advertising } \\
\text { type on conceptual PK (concep- } \\
\text { tual PK for personalized ads is } \\
\text { higher if a disclosure is present) }\end{array}$ \\
\hline 5 & $\begin{array}{l}\text { Sponsored } \\
\text { vlogs }\end{array}$ & $\begin{array}{l}11 \text { to } 14 \\
\text { years }\end{array}$ & $\begin{array}{l}\text { Presence of a } \\
\text { disclosure (no } \\
\text { disclosure vs. } \\
\text { disclosure) }\end{array}$ & $\begin{array}{l}\text { Para-social } \\
\text { interaction }\end{array}$ & $\begin{array}{l}\text { Peer-based } \\
\text { advertising } \\
\text { literacy inter- } \\
\text { vention }\end{array}$ & $\begin{array}{l}\text { Purchase inten- } \\
\text { tion }\end{array}$ & - \\
\hline 6 & $\begin{array}{l}\text { Vlog adver- } \\
\text { tising }\end{array}$ & $\begin{array}{l}10 \text { to } 12 \\
\text { years }\end{array}$ & $\begin{array}{l}\text { Disclosure } \\
\text { types (platform- } \\
\text { generated (PG) } \\
\text { disclosure vs. } \\
\text { no PG disclo- } \\
\text { sure; influencer- } \\
\text { generated (IG) } \\
\text { disclosure: } \\
\text { commercial } \\
\text { interference } \\
\text { disclosure vs. } \\
\text { no commercial } \\
\text { interference vs. } \\
\text { no IG disclo- } \\
\text { sure) }\end{array}$ & & & $\begin{array}{l}\text { Conceptual PK } \\
\text { (recognition } \\
\text { of advertising, } \\
\text { insight into the } \\
\text { tactic of the } \\
\text { brand, insight } \\
\text { into the tactic } \\
\text { of the influenc- } \\
\text { er) / attitudinal } \\
\text { PK }\end{array}$ & $\begin{array}{l}\text { - Positive main effects of both } \\
\text { PG and IG disclosures on recog- } \\
\text { nition of advertising } \\
\text { - Positive main effects of IG } \\
\text { disclosure on other compo- } \\
\text { nents of conceptual PK and } \\
\text { attitudinal PK } \\
\text { - No main effects of PG disclosure } \\
\text { on other components of concep- } \\
\text { tual PK and attitudinal PK }\end{array}$ \\
\hline
\end{tabular}




\begin{tabular}{|c|c|c|c|c|c|c|c|}
\hline Nr. & $\begin{array}{l}\text { Advertising } \\
\text { Type }\end{array}$ & $\begin{array}{l}\text { Stage of } \\
\text { Devel- } \\
\text { opment }\end{array}$ & $\begin{array}{l}\text { Independent } \\
\text { Variable(s) }\end{array}$ & Mediator(s) & Moderator(s) & $\begin{array}{l}\text { Dependent } \\
\text { Variable(s) }\end{array}$ & $\begin{array}{l}\text { Effects of Advertising Disclo- } \\
\text { sures on } \mathrm{PK}^{\star}\end{array}$ \\
\hline \multirow[t]{2}{*}{7} & \multirow[t]{2}{*}{$\begin{array}{l}\text { Product } \\
\text { placements } \\
\text { and online } \\
\text { banner } \\
\text { advertising }\end{array}$} & $\begin{array}{l}6 \text { to } 12 \\
\text { years } \\
\text { (eye- } \\
\text { track- } \\
\text { ing) }\end{array}$ & $\begin{array}{l}\text { Disclosure type } \\
\text { (six disclosure } \\
\text { designs) }\end{array}$ & - & - & Visual attention & - \\
\hline & & $\begin{array}{l}10 \text { to } 11 \\
\text { years } \\
\text { (experi- } \\
\text { ment) }\end{array}$ & $\begin{array}{l}\text { Disclosure type } \\
\text { (existing vs. } \\
\text { child-inspired } \\
\text { disclosure) }\end{array}$ & - & $\begin{array}{l}\text { Advertising } \\
\text { type }\end{array}$ & $\begin{array}{l}\text { Disclosure } \\
\text { recognition } \\
\text { / disclosure } \\
\text { understanding } \\
\text { / disclosure } \\
\text { preference / } \\
\text { conceptual PK } \\
\text { (advertising } \\
\text { recognition) }\end{array}$ & $\begin{array}{l}\text { - Positive main effect of dis- } \\
\text { closure type on conceptual } \\
\text { PK (child-inspired disclosure } \\
\text { increases conceptual PK com- } \\
\text { pared to existing disclosure) }\end{array}$ \\
\hline \multirow[t]{2}{*}{8} & \multirow[t]{2}{*}{$\begin{array}{l}\text { Product } \\
\text { placements }\end{array}$} & \multirow[t]{2}{*}{$\begin{array}{l}8 \text { to } 10 \\
\text { years }\end{array}$} & $\begin{array}{l}\text { Disclosure } \\
\text { modality (no vs. } \\
\text { visual vs. audi- } \\
\text { tory disclosure) }\end{array}$ & $\begin{array}{l}\text { Conceptual PK } \\
\text { (recognition } \\
\text { of advertising, } \\
\text { understanding } \\
\text { of commercial } \\
\text { source, and } \\
\text { understanding } \\
\text { of persuasive } \\
\text { intent) }\end{array}$ & - & Brand attitude & $\begin{array}{l}\text { - Positive main effect of disclo- } \\
\text { sure condition on conceptual } \\
\text { PK (visual and auditory disclo- } \\
\text { sure increase PK compared to } \\
\text { no disclosure; but no differences } \\
\text { between visual and auditory } \\
\text { disclosure) }\end{array}$ \\
\hline & & & $\begin{array}{l}\text { Disclosure } \\
\text { timing (before } \\
\text { movie excerpt } \\
\text { vs. during the } \\
\text { whole movie } \\
\text { fragment) }\end{array}$ & $\begin{array}{l}\text { Conceptual PK } \\
\text { (measures as in } \\
\text { model } 1 \text { ) }\end{array}$ & $\begin{array}{l}\text { Attitude toward } \\
\text { ad format }\end{array}$ & Brand attitude & $\begin{array}{l}\text { - Positive main effect of disclo- } \\
\text { sure condition on conceptual } \\
\text { PK (disclosure before movie } \\
\text { excerpt increases PK) }\end{array}$ \\
\hline 9 & Advergames & $\begin{array}{l}6 \text { to } 12 \\
\text { years }\end{array}$ & $\begin{array}{l}\text { Advergame } \\
\text { type (energy- } \\
\text { dense snacks } \\
\text { vs. nonfood } \\
\text { products) and } \\
\text { presence of a } \\
\text { disclosure (no } \\
\text { disclosure vs. } \\
\text { disclosure) }\end{array}$ & - & - & Caloric intake & - \\
\hline \multirow[t]{2}{*}{10} & \multirow[t]{2}{*}{$\begin{array}{l}\text { In-vlog } \\
\text { advertising }\end{array}$} & \multirow[t]{2}{*}{$\begin{array}{l}7 \text { to } 16 \\
\text { years }\end{array}$} & $\begin{array}{l}\text { Presence of a } \\
\text { disclosure (no } \\
\text { disclosure vs. } \\
\text { disclosure) }\end{array}$ & $\begin{array}{l}\text { Conceptual PK } \\
\text { (advertising } \\
\text { recognition, } \\
\text { understanding } \\
\text { of commercial } \\
\text { intent) }\end{array}$ & $\begin{array}{l}\text { Dispositional } \\
\text { PK/ age }\end{array}$ & Brand attitude & $\begin{array}{l}\text { - No main effect of the use of } \\
\text { disclosures on conceptual PK } \\
\text { (dispositional PK did not mod- } \\
\text { erate this effect; no three-way } \\
\text { interaction between disclosure, } \\
\text { dispositional PK, and age on } \\
\text { conceptual PK) }\end{array}$ \\
\hline & & & $\begin{array}{l}\text { Presence of a } \\
\text { disclosure (no } \\
\text { disclosure vs. } \\
\text { disclosure) }\end{array}$ & Attitudinal PK & $\begin{array}{l}\text { Dispositional } \\
\text { PK/ age }\end{array}$ & Brand attitude & $\begin{array}{l}\text { - No main effect of the use of } \\
\text { disclosures on attitudinal PK } \\
\text { (dispositional PK did not mod- } \\
\text { erate this effect; no three-way } \\
\text { interaction between disclosure, } \\
\text { dispositional PK, and age on } \\
\text { attitudinal PK) }\end{array}$ \\
\hline 11 & $\begin{array}{l}\text { TV and print } \\
\text { advertise- } \\
\text { ment }\end{array}$ & $\begin{array}{l}8 \text { to } 11 \\
\text { years }\end{array}$ & $\begin{array}{l}\text { Food health } \\
\text { warnings }\end{array}$ & - & - & Visual attention & - \\
\hline
\end{tabular}




\begin{tabular}{|c|c|c|c|c|c|c|c|}
\hline Nr. & $\begin{array}{l}\text { Advertising } \\
\text { Type }\end{array}$ & $\begin{array}{l}\text { Stage of } \\
\text { Devel- } \\
\text { opment }\end{array}$ & $\begin{array}{l}\text { Independent } \\
\text { Variable(s) }\end{array}$ & Mediator(s) & Moderator(s) & $\begin{array}{l}\text { Dependent } \\
\text { Variable(s) }\end{array}$ & $\begin{array}{l}\text { Effects of Advertising Disclo- } \\
\text { sures on } \mathrm{PK}^{\star}\end{array}$ \\
\hline \multirow[t]{2}{*}{12} & \multirow[t]{2}{*}{ Advergames } & \multirow[t]{2}{*}{$\begin{array}{l}7 \text { to } 10 \\
\text { years }\end{array}$} & $\begin{array}{l}\text { Conceptual PK } \\
\text { (understanding } \\
\text { of commercial } \\
\text { source and } \\
\text { understanding } \\
\text { of persuasive } \\
\text { intent) }\end{array}$ & - & $\begin{array}{l}\text { Presence of a } \\
\text { disclosure (no } \\
\text { disclosure vs. } \\
\text { disclosure) }\end{array}$ & $\begin{array}{l}\text { Purchase re- } \\
\text { quest }\end{array}$ & - \\
\hline & & & $\begin{array}{l}\text { Attitude toward } \\
\text { ad format }\end{array}$ & - & $\begin{array}{l}\text { Presence of a } \\
\text { disclosure (no } \\
\text { disclosure vs. } \\
\text { disclosure) }\end{array}$ & $\begin{array}{l}\text { Purchase re- } \\
\text { quest }\end{array}$ & - \\
\hline 13 & $\begin{array}{l}\text { TV adver- } \\
\text { tisement }\end{array}$ & $\begin{array}{l}8 \text { to } 10 \\
\text { years }\end{array}$ & $\begin{array}{l}\text { Disclosure type } \\
\text { (no disclosure } \\
\text { vs. commercial } \\
\text { intent disclo- } \\
\text { sure vs. manip- } \\
\text { ulative intent } \\
\text { disclosure) }\end{array}$ & $\begin{array}{l}\text { Conceptual PK } \\
\text { (understanding } \\
\text { of selling intent, } \\
\text { understanding } \\
\text { of persuasive } \\
\text { intent) and at- } \\
\text { titudinal PK }\end{array}$ & $\begin{array}{l}\text { Additional } \\
\text { prompt (no } \\
\text { prompt vs. } \\
\text { additional } \\
\text { prompt) }\end{array}$ & Product desire & $\begin{array}{l}\text { - No main effects of disclosure } \\
\text { types on conceptual PK } \\
\text { - Negative indirect effect of } \\
\text { manipulative intent disclosure } \\
\text { on product desire compared } \\
\text { to commercial intent and no } \\
\text { disclosure through higher at- } \\
\text { titudinal PK }\end{array}$ \\
\hline 14 & $\begin{array}{l}\text { Product } \\
\text { placements }\end{array}$ & $\begin{array}{l}6 \text { to } 11 \\
\text { years }\end{array}$ & $\begin{array}{l}\text { Disclosure } \\
\text { repetition (no } \\
\text { disclosure } \\
\text { vs. one-time } \\
\text { disclosure vs. } \\
\text { repeated disclo- } \\
\text { sure) }\end{array}$ & $\begin{array}{l}\text { Visual attention } \\
\text { to placement }\end{array}$ & Age & $\begin{array}{l}\text { Conceptual PK } \\
\text { (understanding } \\
\text { of commercial } \\
\text { source, un- } \\
\text { derstanding } \\
\text { of persuasive } \\
\text { intent) }\end{array}$ & $\begin{array}{l}\text { - No main effect of disclosures } \\
\text { (both repeated and one-time } \\
\text { disclosure compared to no } \\
\text { disclosure) on conceptual PK } \\
\text { - Negative indirect effect of } \\
\text { disclosure repetition compared } \\
\text { to no disclosure and a one-time } \\
\text { disclosure on conceptual PK } \\
\text { through higher visual attention } \\
\text { toward the placement (with no } \\
\text { moderating influence of age for } \\
\text { the relationship between visual } \\
\text { attention and PK) }\end{array}$ \\
\hline 15 & $\begin{array}{l}\text { Product } \\
\text { placements }\end{array}$ & $\begin{array}{l}9 \text { to } 15 \\
\text { years }\end{array}$ & $\begin{array}{l}\text { Disclosure } \\
\text { repetition (no } \\
\text { vs. single vs. } \\
\text { double disclo- } \\
\text { sure) }\end{array}$ & - & Age & $\begin{array}{l}\text { Conceptual PK } \\
\text { (advertising } \\
\text { recognition) } \\
\text { / brand out- } \\
\text { comes (recall, } \\
\text { preference) }\end{array}$ & $\begin{array}{l}\text { - Positive main effect of the use } \\
\text { of disclosures on conceptual } \\
\text { PK (differences between no } \\
\text { disclosure and double disclo- } \\
\text { sure; no differences between no } \\
\text { disclosure and single disclosure) } \\
\text { - Both single and double disclo- } \\
\text { sures increase PK (compared to } \\
\text { no disclosure) } \\
\text { - no interaction effect of use of } \\
\text { disclosures and age }\end{array}$ \\
\hline
\end{tabular}




\begin{tabular}{|c|c|c|c|c|c|c|c|}
\hline Nr. & $\begin{array}{l}\text { Advertising } \\
\text { Type }\end{array}$ & \begin{tabular}{|l|} 
Stage of \\
Devel- \\
opment
\end{tabular} & $\begin{array}{l}\text { Independent } \\
\text { Variable(s) }\end{array}$ & Mediator(s) & Moderator(s) & $\begin{array}{l}\text { Dependent } \\
\text { Variable(s) }\end{array}$ & $\begin{array}{l}\text { Effects of Advertising Disclo- } \\
\text { sures on } \mathrm{PK}^{\star}\end{array}$ \\
\hline \multirow[t]{2}{*}{16} & \multirow[t]{2}{*}{$\begin{array}{l}\text { Product } \\
\text { placements }\end{array}$} & \multirow[t]{2}{*}{\begin{tabular}{|l|}
13 to 17 \\
years
\end{tabular}} & $\begin{array}{l}\text { Presence of a } \\
\text { disclosure (no } \\
\text { disclosure vs. } \\
\text { disclosure) }\end{array}$ & $\begin{array}{l}\text { Conceptual PK } \\
\text { (advertising } \\
\text { recognition, } \\
\text { understanding } \\
\text { of persuasive } \\
\text { intent) and at- } \\
\text { titudinal PK }\end{array}$ & - & $\begin{array}{l}\text { Brand out- } \\
\text { comes (mem- } \\
\text { ory, attitude } \\
\text { toward the } \\
\text { brand) }\end{array}$ & $\begin{array}{l}\text { - No main effect of the use of } \\
\text { disclosures (both 3-second dis- } \\
\text { closure and 6-second disclosure } \\
\text { compared to no disclosure) on } \\
\text { recognition of advertising and } \\
\text { attitudinal PK } \\
\text { - Positive main effect of the use } \\
\text { of disclosures on understand- } \\
\text { ing of persuasive intent (but } \\
\text { only among participants who } \\
\text { remembered the disclosure) } \\
\text { - No indirect effects of disclosure } \\
\text { on attitudinal PK, mediated by } \\
\text { recognition of advertising or un- } \\
\text { derstanding of persuasive intent }\end{array}$ \\
\hline & & & $\begin{array}{l}\text { Disclosure } \\
\text { duration (no } \\
\text { disclosure vs. } \\
\text { 3-second vs. } \\
\text { 6-second dis- } \\
\text { closure) }\end{array}$ & - & - & $\begin{array}{l}\text { Conceptual } \\
\text { (same meas- } \\
\text { ures as above) } \\
\text { and attitudinal } \\
\text { PK / brand } \\
\text { outcomes } \\
\text { (memory, atti- } \\
\text { tude toward the } \\
\text { brand) }\end{array}$ & $\begin{array}{l}\text { - No main effect of disclosure } \\
\text { condition on conceptual PK and } \\
\text { attitudinal PK (also among only } \\
\text { participants who remembered } \\
\text { the disclosure) }\end{array}$ \\
\hline 17 & $\begin{array}{l}\text { Sponsored } \\
\text { influencer } \\
\text { videos }\end{array}$ & $\begin{array}{l}10 \text { to } 13 \\
\text { years }\end{array}$ & \begin{tabular}{|l|} 
Disclosure \\
timing (no \\
disclosure vs. \\
prior disclosure \\
vs. concurrent \\
disclosure) \\
\end{tabular} & $\begin{array}{l}\text { Visual attention } \\
\text { to disclosure } \\
\text { / disclosure } \\
\text { recognition / } \\
\text { conceptual PK } \\
\text { (advertising } \\
\text { recognition) / } \\
\text { attitudinal PK }\end{array}$ & - & $\begin{array}{l}\text { Brand out- } \\
\text { comes (atti- } \\
\text { tude, behavio- } \\
\text { ral intention) }\end{array}$ & $\begin{array}{l}\text { - No main effect of disclosure } \\
\text { condition on conceptual PK } \\
\text { - Positive indirect effect of prior } \\
\text { disclosure on PK compared to } \\
\text { concurrent and no disclosure } \\
\text { through higher visual attention } \\
\text { to disclosure and disclosure } \\
\text { recognition }\end{array}$ \\
\hline 18 & $\begin{array}{l}\text { Sponsored } \\
\text { influencer } \\
\text { videos }\end{array}$ & $\begin{array}{l}12 \text { to } 16 \\
\text { years }\end{array}$ & $\begin{array}{l}\text { Disclosure type } \\
\text { (no disclosure } \\
\text { vs. advertising } \\
\text { disclosure vs. } \\
\text { advertising and } \\
\text { intent disclo- } \\
\text { sure) }\end{array}$ & $\begin{array}{l}\text { Conceptual PK } \\
\text { (advertising } \\
\text { recognition, } \\
\text { understanding } \\
\text { of persuasive } \\
\text { intent) and at- } \\
\text { titudinal PK }\end{array}$ & Age & $\begin{array}{l}\text { Brand out- } \\
\text { comes (atti- } \\
\text { tude, purchase } \\
\text { intent) }\end{array}$ & $\begin{array}{l}\text { - Positive main effect of the use } \\
\text { of disclosures on conceptual } \\
\text { PK (both disclosure types in- } \\
\text { crease advertising recognition } \\
\text { compared to no disclosure but } \\
\text { no differences between disclo- } \\
\text { sure types; the advertising and } \\
\text { intent disclosure led to highest } \\
\text { scores of understanding of } \\
\text { persuasive intent) } \\
\text { - Interaction effect of disclosure } \\
\text { type and age }\end{array}$ \\
\hline 19 & $\begin{array}{l}\text { TV adver- } \\
\text { tisement } \\
\text { and website } \\
\text { advertising }\end{array}$ & $\begin{array}{l}5 \text { to } 11 \\
\text { years }\end{array}$ & \begin{tabular}{l|} 
Advertising type \\
(TV vs. website); \\
disclosure type \\
(no vs. low- \\
prominent vs. \\
high-prominent \\
disclosure)
\end{tabular} & - & Age & $\begin{array}{l}\text { Conceptual PK } \\
\text { (recognition of } \\
\text { advertising) }\end{array}$ & $\begin{array}{l}\text { - Positive main effect of the use } \\
\text { of disclosures on conceptual } \\
\text { PK (but no differences between } \\
\text { disclosure conditions) } \\
\text { - Positive main effect of age on } \\
\text { conceptual PK (but no interac- } \\
\text { tion effect of disclosures and } \\
\text { age) }\end{array}$ \\
\hline
\end{tabular}

Tab. 1.: Overview of Sampled Studies. Notes: *Persuasion knowledge. If studies include more than one model or if a publication comprises a two-study design, models are presented separately. Not significant results are shown in italics. 


\section{Results}

\subsection{Potential Advertising Disclosure Effects on Persuasion Knowledge (RQ1)}

\section{Conceptual Persuasion Knowledge}

A great amount of the $N=19$ included studies concentrated on how advertising disclosures affect the activation of different components of children's conceptual persuasion knowledge $(n=14)$. These studies treated conceptual persuasion knowledge as a mediator or dependent variable and advertising disclosures as independent variables or moderators. Table 1 specifies the components of the conceptual persuasion knowledge researched within each study.

The results of these studies show that advertising disclosures only partly foster components of children's conceptual persuasion knowledge. More precisely, in several studies $(n=6)$, no main or moderating effects of the use of disclosures on the components of conceptual persuasion knowledge were found (study no. 1, nr. 10, no. 13 , no. 14 , no. 16 , and no. 17). In contrast, a total of $n=9$ studies perceived positive main or moderating effects of advertising disclosures on children's conceptual persuasion knowledge. These effects, however, are limited to specific components of persuasion knowledge. In other words, most of these detected positive effects only relate to the recognition of advertising (i.e., the first component of conceptual persuasion knowledge as in study no. 2 , no. 6 , no. 7 , no. 15 , no. 18 , and no. 19). Furthermore, some of the included studies only found effects for other components, including children's understanding of persuasive intent (study no. 2, no. 18, and no. 16) and selling intent (study no. 2 and no. 4). Moreover, in two studies these effects only appeared among children who remembered seeing the disclosure (study no. 2 and no. 16).

It must be stressed that the measurements of these studies also differed, especially in the number of items, meaning that some studies measured a component of conceptual persuasion knowledge with a single item (e.g., study no. 4) while other studies depicted a specific component through several items (e.g., study no. 2). Furthermore, a large number of the $N=19$ sampled studies used an index for conceptual persuasion knowledge that summarized several components. This also includes one study that revealed a positive effect of the use of disclosures on children's conceptual knowledge of persuasion (study no. 8). It must be pointed out that the use of such 'partial' and different measurements for conceptual knowledge (see e.g., Boerman et al. 2018) of course makes it more difficult to make a clear statement on how advertising disclosures affect children's conceptual persuasion knowledge. 
Additionally, some individual studies also revealed the indirect effects of advertising disclosures on components of children's conceptual persuasion knowledge (study no. 14 and no. 17). These indirect effects of disclosures on children's knowledge of persuasion were mediated by the extent of the children's visual attention toward the subsequently placed brand placement (study no. 14) and by the children's visual attention toward the disclosure and disclosure recognition as a serial mediator (study no. 17). Whether these indirect effects turned out to be positive (study no. 17) or negative (study no. 14) was contingent upon specific disclosure characteristics, which thus become determining factors.

\section{Attitudinal Persuasion Knowledge}

Some of the sampled studies $(n=6)$ also paid special attention to children's attitudinal persuasion knowledge (study no. 6 , no. 10 , no. 13 , no. 16 , no. 17 , and nr. 18). The authors Hoek et al. (2020) (study no. 10) report no main effects of the use of disclosures on children's attitudinal persuasion knowledge. Also, in the study of Rozendaal, Buijs, and van Reijmersdal (2016) (study no. 13), no disclosure effects for attitudinal persuasion knowledge were found. Instead, children's attitudinal persuasion knowledge served as a mediator for the effect of disclosure conditions on product desire.

Furthermore, the authors van Reijmersdal et al. (2017) (study no. 16) investigate whether children's conceptual persuasion knowledge (assessed by the recognition of advertising and understanding of its persuasive intent) mediates the effect of the use of disclosures on attitudinal persuasion knowledge. However, their analyses show no indirect effects. Moreover, the results of one recently published study by van Reijmersdal and van Dam (2020) (study no. 18) do not indicate that children's higher conceptual persuasion knowledge is automatically associated with higher attitudinal persuasion knowledge. However, depending on disclosure type, children's advertising recognition and understanding of persuasive intent (i.e., conceptual persuasion knowledge) improve in children in later developmental stages (middle adolescent), which ultimately results in higher attitudinal persuasion knowledge. In contrast, children who belong to earlier developmental stages (early adolescent) remain unaffected.

Also, recent findings of De Jans and Hudders (2020) (study no. 6) demonstrate that children's attitudinal persuasion knowledge (assessed by their skepticism toward the ad) was more activated when the influencer disclosed that there was a commercial interference of the brand as compared to no commercial interference disclosure (but not compared to no influencer-generated disclosure). These results again emphasize that determining factors might be responsible for the emergence of advertising disclosure effects. 


\subsection{Determining Factors for Advertising Disclosure Effects on Persuasion Knowledge} (RQ2)

As described above, the literature on persuasion knowledge suggests the presence of factors that can increase or inhibit the process of persuasion knowledge activation and development in children. These determining factors can be divided into individual, environmental, and situational factors.

When examining determining factors for advertising disclosures' effects on children's persuasion knowledge, we can build on existing persuasion knowledge literature and investigate whether factors identified in this research field can be also transferred to the context of advertising disclosures. Prior to this, we can detect additional factors that also receive scientific attention in this research field (RQ2a). The results of the literature review are presented below according to the respective factors.

\section{Advertising Disclosures Factors}

Some of the sampled studies examined what kind of determining factors lead to advertising disclosure effects. This first includes advertising disclosures factors $(n=11)$. However, half of these studies reveal no effects of advertising disclosure factors on children's persuasion knowledge. This includes disclosure modality (study no. 1), disclosure type (study no. 13, no. 18, and no. 19), and disclosure duration (study no. 16). Other studies show that specific advertising disclosure factors can affect children's knowledge of persuasion both in direct (study no. 6 , no. 7 , no. 8 , no. 15 , and no. 18) and indirect (study no. 14 and no. 17) ways.

When starting with the direct effects, authors De Jans et al. (2018) (study no. 7) reveal that children's level of persuasion knowledge differs depending on disclosure type. More specifically, a self-created disclosure suitable for children (through the use of flashy colors and other wording based on cocreation workshops with children) increased the children's conceptual persuasion knowledge as compared to the existing disclosure used in practice. Furthermore, a study published by van Reijmersdal and van Dam (2020) (study no. 18) shows that both disclosure types investigated ("only advertising" disclosure versus "advertising and intent" disclosure) increased children's advertising recognition as compared to no disclosure. However, the authors found differences between the two types of disclosures for another component of conceptual persuasion knowledge. More precisely, the "advertising and intent" disclosure led to the highest scores in children's understanding of persuasive intent as compared to both the "only advertising" disclosure and no disclosure. This effect between the disclosure types was not found for children's advertising recognition.

Moreover, a study of De Pauw and colleagues (2018) (study no. 8) indicates that disclosure modality and disclosure timing can affect children's conceptual persuasion knowledge. Their empirical findings suggest that using both a visual and 
auditory disclosure increases children's knowledge of persuasion as compared to no disclosure. However, no differences between visual and auditory disclosure were found. Regarding disclosure timing, an advertising disclosure shown before the film clip significantly increased young consumers' persuasion knowledge as compared to an advertising disclosure cue shown during the movie excerpt (De Pauw, Hudders, and Cauberghe 2018). Additionally, a study on disclosure repetition (study no. 15) indicates that the presence of disclosures can lead to an increase in children's recognition of advertising as compared to no disclosure (Uribe and Fuentes-García 2020). The authors also found that advertising recognition was higher for double disclosures than for single disclosures.

As stated above, individual studies also reveal indirect effects of advertising disclosures on components of children's conceptual persuasion knowledge (study no. 14 and no. 17). However, whether these indirect effects occurred was contingent upon disclosure repetition and timing. Regarding the latter, the authors van Reijmersdal et al. (2020) (study no. 17) reveal a positive indirect effect of disclosures shown prior the branded content on children's level of conceptual persuasion knowledge as compared to disclosures shown concurrent with branded content and to no disclosures. This effect was mediated by higher levels of visual attention toward the disclosure as well as by higher levels of disclosure recognition (serial mediator). In terms of disclosure repetition, the authors Spielvogel, Naderer, and Matthes 2020 (study no. 14) show that, through higher levels of visual attention paid toward the subsequent placement, repeated disclosures negatively affected children's conceptual persuasion knowledge as compared to one-time disclosures and to no disclosures.

\section{Individual Factors}

When examining determining factors for the effects of advertising disclosures on children's persuasion knowledge, individual factors have also been the subject of investigation $(n=5)$. More specifically, the moderating influence of children's age has been examined in these studies. However, the majority of previous studies find no moderating influence of age for the direct or indirect effects of advertising disclosures on children's knowledge of persuasion (study no. 10, no. 14, no. 15, and no. 19).

In contrast, the results of only one recently published study of the authors van Reijmersdal and van Dam (2020) (study no. 18) reveal significant interaction effects. Based on their findings, both of their investigated disclosure types ("disclosure of advertising" versus "disclosure of advertising and intent") can increase conceptual persuasion knowledge among middle adolescents. In the case of early adolescents, however, only "advertising and intent" disclosures were able to improve their knowledge of persuasion. Hence, only a more detailed disclosure appears to be an effective means of alerting younger adolescents that the upcoming YouTube video of an influencer contains advertising. 


\section{Environmental and Situational Factors}

Surprisingly, none of the sampled studies investigate the moderating influence of environmental and situational factors for the effect of disclosure presence on children's knowledge of persuasion. To my knowledge, only one study examines the moderating influence of having a para-social relationship with the influencer (study no. 2) for the effect of conceptual persuasion knowledge on brand-related outcomes.

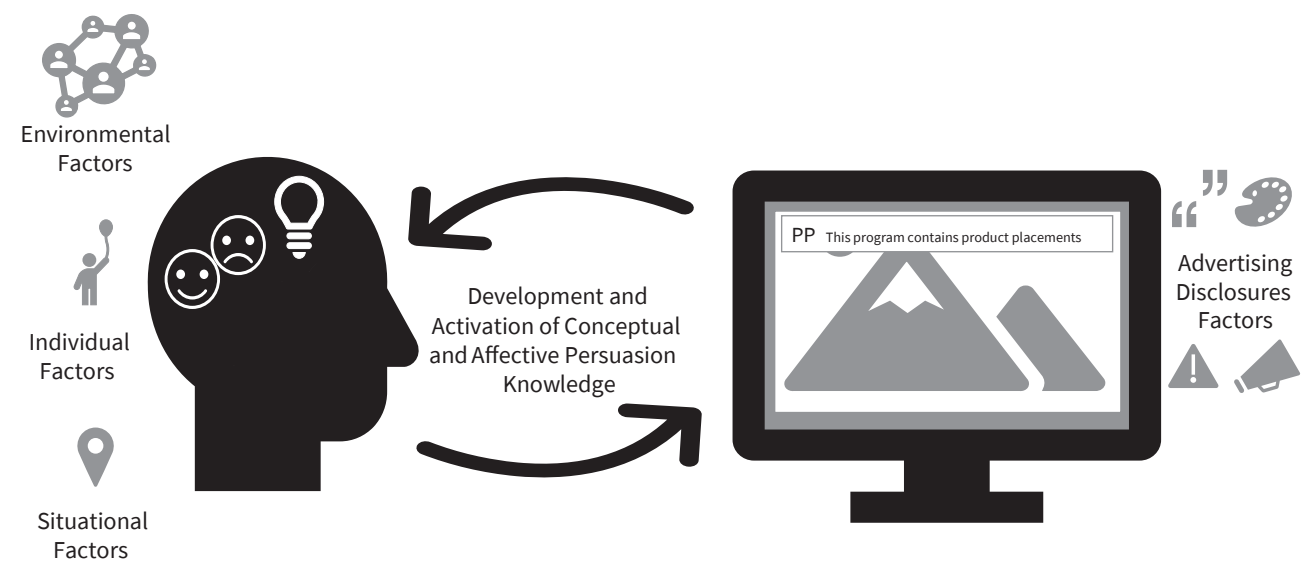

Fig. 1.: Conceptual Model. Source: Author.

Figure 1 depicts the conceptual model of the present study. The conceptualization is based on the determining factors that have been covered by previous advertising disclosure research in connection with children (i.e., advertising disclosures factors and individual factors). It further includes factors culled from persuasion knowledge literature that might also be responsible for advertising disclosure effectiveness in children (i.e., environmental and situational factors). The potential role these factors may play in a more understandable disclosure on children will be discussed in the following chapter (RQ2b). Additionally, other potential factors that could be important in this context but have not received any scientific attention at this time are discussed. Therefore, this discussion outlines opportunities for future research.

\section{Discussion}

Based on the results of the literature review, a large portion of previous empirical research on advertising disclosures and children focus on persuasion outcomes. This also includes the activation of persuasion knowledge in terms of the brand to which children are exposed. It follows that it remains unclear which factors might be especially important in this context and potential moderators. 


\subsection{Advertising Disclosures Factors}

The previous findings on how advertising disclosures affects children appear to be mixed and insufficient. Half of these studies reveal no effects of advertising disclosure factors on children's persuasion knowledge. Other studies show that specific advertising disclosures factors can affect children's knowledge of persuasion, including disclosure type and content, modality, timing, and repetition. These factors thus seem to play important roles for the argument that advertising disclosures can effectively communicate their message and merit more attention of scholars in the future (De Jans et al. 2019).

While a greater part of advertising disclosure factors examined were theoretically derived from disclosure studies with adults (van Reijmersdal et al. 2017), other factors such as the repetition of advertising disclosures were found to be especially relevant in connection with children (Spielvogel, Naderer, and Matthes 2020; Uribe and Fuentes-García 2020). Scholars thus need to specify other advertising-disclosure factors that might be relevant for young consumers. Against this background, the authors De Jans et al. (2018) aimed to create an advertising disclosure that was more suitable for children. By doing so, they paid special attention to the visual appearance of the disclosure. During cocreation workshops with children, an eye-tracking study tested various disclosure designs which differed in their visual appearance (e.g., color, font size) and format (e.g., symbols, exclamation marks). Future research is highly encouraged to test which additional visual appearances are most suitable for children.

Furthermore, it is advisable to test how the visual appearance of various advertising disclosures not only affects children's visual attention but also children's disclosure awareness, disclosure understanding, and knowledge of persuasion. Special focus should be given to symbols, especially when it comes to young children whose reading skills are still developing.

\subsection{Individual Factors}

In terms of individual factors, it becomes apparent that previous advertising disclosure studies in connection with children build on persuasion knowledge research. In other words, it is assumed that individual factors such as age do not only directly improve children's knowledge of persuasion, while also moderating advertising disclosures effects on persuasion knowledge activation. However, in most of the included studies the effect of advertising disclosures on children's knowledge of persuasion is not contingent on young consumers' developmental stages.

Despite this fact, individual factors other than children's age receive little to no attention by scholars in this research field. Age as a crucial factor for persuasion knowledge development might be less important than previously theorized (Lapierre 
2017), especially in the case of contemporary advertising targeted at children (Nairn and Fine 2008). Therefore, individual determining factors other than children's age might be very relevant to the success of an advertising disclosure in the sense of being both more understandable and more effective for children.

One piece of advice for future research is to focus more on 'mutable' supporting constructs than on 'immutable' supporting constructs, such as age. This advice builds on the literature on persuasion knowledge. The fact that scholars predominantly use age as a proxy indicator despite persuasion knowledge's having been framed as a cognitive skill is thus called into question (Lapierre 2015). Therefore, when it comes to the question of which individual factors support or reduce the effectiveness of advertising disclosures in children, other factors should be examined. For instance, to my knowledge no study thus far has considered the moderating role of children's reading skills on disclosure effectiveness. However, the wording of advertising disclosures currently used often comprises full sentences (e.g., "PP - This program contains product placement") or only signal words (e.g., "PP - product placement"; see Spielvogel, Naderer, and Matthes 2021). This demonstrates that various advertising disclosures call for fully developed reading skills in consumers and in some cases where only abbreviations are used (e.g., "PP") symbol comprehension.

Inspired by the authors Boerman, van Reijmersdal, and Neijens (2015a), another potential factor might be children's disclosure familiarity. In their study, adult consumers' familiarity with the use of advertising disclosures also increased the chance that the disclosure would be recognized. To my knowledge, this potential moderating influence has not yet been studied in children. However, children who are frequently exposed to advertising disclosures and are thus familiar with these cues may be more likely to be more aware of disclosures.

\subsection{Environmental and Situational Factors}

Compared to the factors listed above, there is a dearth of research in this field concerning determining factors that take the environment and situation into account. However, especially when it comes to children, environmental factors such as family environment are viewed as relevant influencing factors for both advertising effects (Hudders and Cauberghe 2018) and the development of children's advertising skills (Nelson et al. 2017; Terlutter and Spielvogel 2010). This might also be the case for advertising disclosure effects.

Furthermore, situational factors such as the amount of visual attention that consumers pay toward the respective area of interest may not only be relevant for advertising effects but also for advertising disclosure effects. Eye-tracking studies in this context already show that the amount of children's visual attention serves as an important mediator for the effect of advertising disclosures on children's conceptual 
persuasion knowledge (Spielvogel, Naderer, and Matthes 2020; van Reijmersdal et al. 2020). However, moderating situational influences have not been the subject of research thus far.

This circumstance may, however, neglect significant influential factors for advertising disclosure effects. Another potential influential factor that takes situational aspects into account is the consumer's involvement with the media content. There is empirical evidence to support the idea that adult viewers who are highly involved with media content are also less likely to remember the disclosure (Boerman, van Reijmersdal, and Neijens 2015a). These authors conclude that the more viewers engage with a plot, the fewer cognitive resources remain for disclosure processing. Future research could also examine this assumption with children, perhaps, for example, by manipulating involvement (Matthes, Schemer, and Wirth 2007). When it comes to more contemporary advertising formats such as advergames, children's experience of game flow may not only be positively associated with persuasion knowledge (Vanwesenbeeck, Ponnet, and Walrave 2016) but also explain the effects of advertising disclosures.

\subsection{The Important Role of Disclosure Awareness}

Finally, it must be pointed out that the results of two of the sampled studies indicate that advertising disclosures affect several components of conceptual persuasion knowledge but only among the children who correctly remembered seeing the disclosure (Boerman and van Reijmersdal 2020; van Reijmersdal et al. 2017). Furthermore, disclosure recognition appears to serve as a mediator for advertising disclosures' effect on children's persuasion knowledge (van Reijmersdal et al. 2020).

These results emphasize that disclosure awareness constitutes a precondition that ensures that an advertising disclosure can have its intended effect on the activation of persuasion knowledge. Studies with adults also emphasize the necessity of disclosure awareness for advertising disclosure effects (Boerman, van Reijmersdal, and Neijens 2012; Boerman, van Reijmersdal, and Neijens 2015a; 2015b). Future research should therefore consider disclosure awareness in more detail. 


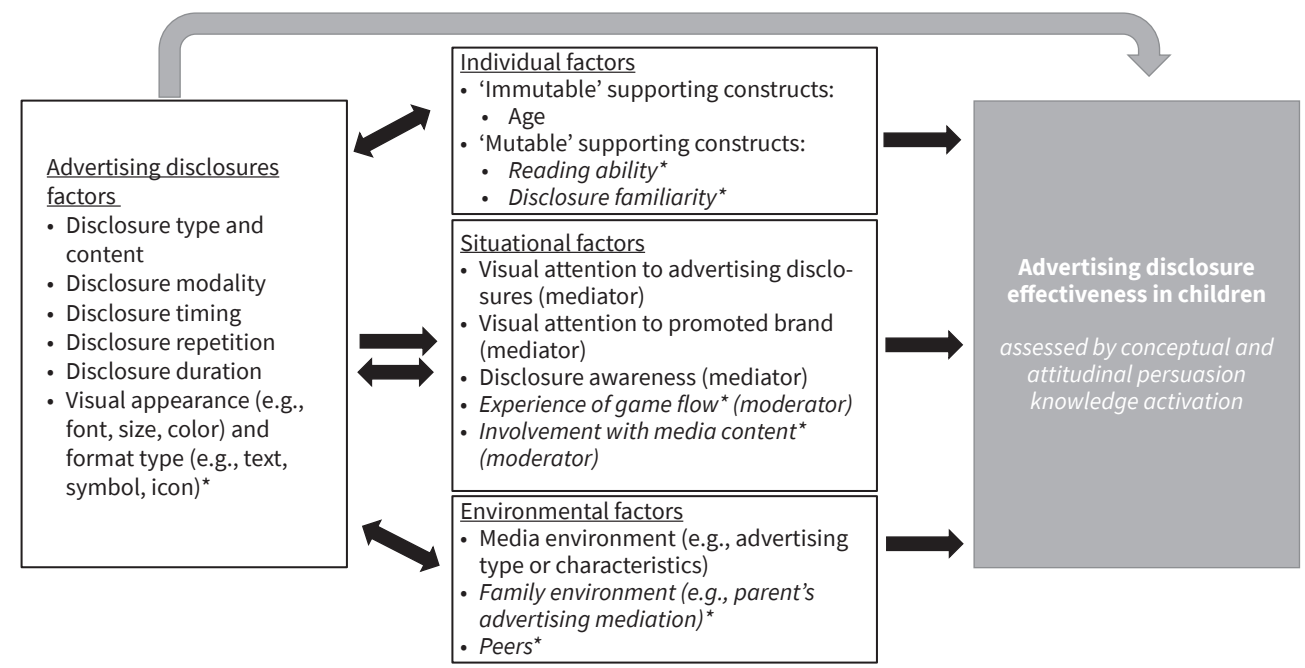

Fig. 2.: Overview of Potential Determining Factors for Advertising Disclosures Effectiveness on Children. Source: Author. Note: *Determining factors that have not yet been tested in the context of advertising disclosures and children's persuasion knowledge.

Figure 2 summarizes the findings and gives an overview of potential determining factors for advertising disclosures' effectiveness on children (assessed by conceptual and attitudinal persuasion knowledge activation). Based on the findings of this literature review of advertising disclosure studies in connection with children, there is a scientific focus on advertising disclosures (factors) and their effects on persuasion outcomes, including children's persuasion knowledge (grey arrow).

Furthermore, Figure 2 depicts all the determining factors that have been addressed in previous research and contains additional identified factors that may be important in this context (shown in italics). Moreover, it is assumed that some factors interact with each other (double-headed arrows). Against this backdrop, several studies pay attention to the interaction effects of advertising disclosures (factors) and individual factors (i.e., age) on children's knowledge of persuasion (e.g., Hoek et al. 2020). Interestingly, one study investigates the interaction between advertising type and the use of disclosures on children's persuasion knowledge (Daems et al. 2019). Although the authors do not examine specific advertising disclosure characteristics, they pay attention to the interplay of disclosures and environmental factors and how this interaction affects children's knowledge of persuasion.

Moreover, in Spielvogel, Naderer, and Matthes (2020), situational factors such as the amount of visual attention children give to the commercial are viewed as important mediators for the effects of disclosures on children's persuasion knowledge. However, situational factors may not only constitute mediators but may also moderate the effects of advertising disclosures (factors) on children's persuasion knowledge. In this light, for instance, Vanwesenbeeck et al. (2016) show that children's experience of game flow is positively associated with children's knowledge of persuasion. 


\section{Conclusion}

The present study presents several scientific implications. In summary, the findings of this literature review indicate that advertising disclosures only partly foster components of children's conceptual persuasion knowledge. That is, some studies reveal positive effects while other found no effects whatsoever. However, these derived effects are only limited to specific components of persuasion knowledge (i.e., usually the first component of conceptual persuasion knowledge, namely recognition of advertising). When considering the findings for both conceptual and attitudinal persuasion knowledge, it is also apparent that determining factors might be responsible for the emergence of advertising disclosure effects.

Above all, future researchers are strongly encouraged to pay more attention to the investigation of the determining factors responsible for advertising disclosure effectiveness in children. Thereby, scholars will be able to build on and expand the proposed conceptualization of determining factors observed and proposed herein. Additionally, it is imperative that researchers provide empirical evidence for the additional factors theoretically derived and proposed by the present study. All of these efforts will enable the discipline as a whole to develop a more effective and understandable conception of advertising disclosure for children.

\section{References}

An, Soontae, and Hannah Kang. 2013. «Do Online Ad Breaks Clearly Tell Kids That Advergames Are Advertisements That Intend to Sell Things?» International Journal of Advertising 32 (4): 655-78. https://doi.org/10.2501/IJA-32-4-655-678.

Auty, Susan, and Charlie Lewis. 2004. «Exploring Children's Choice: The Reminder Effect of Product Placement». Psychology and Marketing 21 (9): 697-713. https://doi.org/10.1002/ mar.20025.

Boerman, Sophie C., and Eva A. van Reijmersdal. 2016. «Informing Consumers about ' Hidden 'Advertising . A Literature Review of the Effects of Disclosing Sponsored Content». In Advertising in New Formats and Media: Current Research and Implications for Marketers, edited by Patrick De Pelsmacker, 115-46. London, UK: Emerald Group Publishing. https://doi. org/10.1108/978-1-78560-313-620151005.

Boerman, Sophie C., and Eva A. van Reijmersdal. 2020. «Disclosing Influencer Marketing on YouTube to Children: The Moderating Role of Para-Social Relationship». Frontiers in Psychology 10 (January): 1-15. https://doi.org/10.3389/fpsyg.2019.03042.

Boerman, Sophie C., Eva A. van Reijmersdal, and Peter C. Neijens. 2012. "Sponsorship Disclosure: Effects of Duration on Persuasion Knowledge and Brand Responses». Journal of Communication 62 (6): 1047-64. https://doi.org/10.1111/j.1460-2466.2012.01677.x.

Boerman, Sophie C., Eva A. van Reijmersdal, and Peter C. Neijens. 2015a. "How Audience and Disclosure Characteristics Influence Memory of Sponsorship Disclosures». International Journal of Advertising 34 (4): 576-92. https://doi.org/10.1080/02650487.2015.1009347. 
Boerman, Sophie C., Eva A. van Reijmersdal, and Peter C. Neijens. 2015b. «Using Eye Tracking to Understand the Effects of Brand Placement Disclosure Types in Television Programs». Journal of Advertising 44 (3): 196-207. https://doi.org/10.1080/00913367.2014.967423.

Boerman, Sophie C., Eva A. van Reijmersdal, Esther Rozendaal, and Alexandra L. Dima. 2018. «Development of the Persuasion Knowledge Scales of Sponsored Content (PKS-SC)». International Journal of Advertising 37 (5): 671-97. https://doi.org/10.1080/02650487.2018. 1470485.

Brown, Callie L., Camden E. Matherne, Cynthia M. Bulik, Janna B. Howard, Sophie N. Ravanbakht, Asheley C. Skinner, Charles T. Wood, et al. 2017. «Influence of Product Placement in Children's Movies on Children's Snack Choices». Appetite 114: 118-24. https://doi. org/10.1016/j.appet.2017.03.022.

Buijzen, Moniek, Eva A. van Reijmersdal, and Laura H. Owen. 2010. «Introducing the PCMC Model: An Investigative Framework for Young People's Processing of Commercialized Media Content». Communication Theory 20 (4): 427-50. https://doi.org/10.1111/j.14682885.2010.01370.x.

Cain Reid, Rita Marie. 2014. «Embedded Advertising to Children: A Tactic That Requires a New Regulatory Approach». American Business Law Journal 51 (4): 721-77. https://doi. org/10.1111/ablj.12038.

Chernin, Ariel. 2007. The Relationship between Children's Knowledge of Persuasive Intent and Persuasion: The Case of Televised Food Marketing. University of Pennsylvania: Retrieved from ProQuest Dissertations and Theses.(Accession Order No. AAI 3292015).

Daems, Kristien, Freya De Keyzer, Patrick De Pelsmacker, and Ingrid Moons. 2019. «Personalized and Cued Advertising Aimed at Children». Young Consumers 20 (2): YC-10-2018-0864. https://doi.org/10.1108/YC-10-2018-0864.

Dam, Sophia van, and Eva A. van Reijmersdal. 2019. "Insights in Adolescents' Advertising Literacy, Perceptions and Responses Regarding Sponsored Influencer Videos and Disclosures». Cyberpsychology: Journal of Psychosocial Research on Cyberspace 13 (2). https://doi. org/10.5817/CP2019-2-2.

Evans, Nathaniel J., and Mariea Grubbs Hoy. 2016. «Parents' Presumed Persuasion Knowledge of Children's Advergames: The Influence of Advertising Disclosure Modality and Cognitive Load». Journal of Current Issues and Research in Advertising 37 (2): 146-64. https://doi.org /10.1080/10641734.2016.1171181.

Evans, Nathaniel J., Mariea Grubbs Hoy, and Courtney Carpenter Childers. 2018. «Parenting "YouTube Natives": The Impact of Pre-Roll Advertising and Text Disclosures on Parental Responses to Sponsored Child Influencer Videos». Journal of Advertising 47 (4): 326-46. https://doi.org/10.1080/00913367.2018.1544952.

Folkvord, Frans, Doeschka J. Anschütz, Reinout W. Wiers, and Moniek Buijzen. 2015. «The Role of Attentional Bias in the Effect of Food Advertising on Actual Food Intake among Children». Appetite 84: 251-58. https://doi.org/10.1016/j.appet.2014.10.016. 
Friestad, Marian, and Peter Wright. 1994. «The Persuasion Knowledge Model: How People Cope with Persuasion Attempts». Journal of Consumer Research 21 (1): 1-31. https://doi. $\operatorname{org} / 10.1086 / 209380$.

Grohs, Reinhard, Heribert Reisinger, Elisabeth Wolfsteiner, and Johanna Haas. 2015. «At What Age and How Does Understanding of Product Placement Develop?' Marketing ZFP 35 (1): 22-31. https://doi.org/10.15358/0344-1369_2013_1_22.

Ham, Chang Dae, Michelle R. Nelson, and Susmita Das. 2015. «How to Measure Persuasion Knowledge». International Journal of Advertising 34 (1): 17-53. https://doi.org/10.1080/02 650487.2014.994730.

Hoek, Rhianne W., Esther Rozendaal, Hein T. van Schie, Eva A. van Reijmersdal, and Moniek Buijzen. 2020. «Testing the Effectiveness of a Disclosure in Activating Children's Advertising Literacy in the Context of Embedded Advertising in Vlogs». Frontiers in Psychology 11 (March): 1-16. https://doi.org/10.3389/fpsyg.2020.00451.

Hudders, Liselot, and Veroline Cauberghe. 2018. «The Mediating Role of Advertising Literacy and the Moderating Influence of Parental Mediation on How Children of Different Ages React to Brand Placements». Journal of Consumer Behaviour, 17 (2): 1-14. https://doi. org/10.1002/cb.1704.

Hudders, Liselot, Veroline Cauberghe, Katerina Panic, and Wendy De Vos. 2016. «Children's Advertising Literacy for New Advertising Formats: The Mediating Impact of Advertising Literacy on the (Un)Intended Effects of Advergames and Advertising Funded Programs» In Advances in Advertising Research VI: The Digital, the Classic, the Subtle, and the Alternative, edited by Peeter Verlegh, Hilde Vooverld, and Martin Eisend, 241-52. European Advertising Academy. Wiesbaden: Springer Gabler. https://doi.org/10.1007/978-3-658-10558-7_19.

Hudders, Liselot, Pieter De Pauw, Veroline Cauberghe, Katarina Panic, Brahim Zarouali, and Esther Rozendaal. 2017. "Shedding New Light on How Advertising Literacy Can Affect Children's Processing of Embedded Advertising Formats: A Future Research Agenda». Journal of Advertising 46 (2): 333-49. https://doi.org/10.1080/00913367.2016.1269303.

Hudson, Simon, David Hudson, and John Peloza. 2008. «Meet the Parents: A Parents' Perspective on Product Placement in Children's Films». Journal of Business Ethics 80 (2): 289-304. https://doi.org/10.1007/s10551-007-9421-5.

Jans, Steffi De, Liselot Hudders, and Veroline Cauberghe. 2018. «Adolescents' Self-Reported Level of Dispositional Advertising Literacy: How Do Adolescents Resist Advertising in the Current Commercial Media Environment?' Young Consumers 19 (4): 402-20. https://doi. org/10.1108/YC-02-2018-00782.

Jans, Steffi De, Dieneke Van de Sompel, Liselot Hudders, and Veroline Cauberghe. 2019. «Advertising Targeting Young Children: An Overview of 10 Years of Research (2006-2016)». International Journal of Advertising 38 (2): 173-206. https://doi.org/10.1080/02650487.2017 .1411056 .

Jans, Steffi De, Ini Vanwesenbeeck, Veroline Cauberghe, Liselot Hudders, Esther Rozendaal, and Eva A. van Reijmersdal. 2018. «The Development and Testing of a Child-Inspired Advertising Disclosure to Alert Children to Digital and Embedded Advertising». Journal of Advertising 47 (3): 255-69. https://doi.org/10.1080/00913367.2018.1463580. 
John, Deborah Roedder. 1999. «Consumer Socialization of Children: A Retrospective Look at Twenty-five Years of Research». Journal of Consumer Research 26 (3): 183-213. https://doi. org/10.1086/209559.

Lapierre, Matthew A. 2015. «Development and Persuasion Understanding: Predicting Knowledge of Persuasion/Selling Intent from Children's Theory of Mind». Journal of Communication 65 (3): 423-42. https://doi.org/10.1111/jcom.12155.

Lapierre, Matthew A. 2017. «Advertising Literacy and Executive Function: Testing Their Influence on Children's Consumer Behavior». Media Psychology 22 (1): 39-59. https://doi.org/1 $0.1080 / 15213269.2017 .1345638$.

Matthes, Jörg, Christian Schemer, and Werner Wirth. 2007. «More than Meets the Eye. Investigating the Hidden Impact of Brand». International Journal of Advertising 26 (4): 477-503. https://doi.org/10.1080/02650487.2007.11073029.

Naderer, Brigitte, Jörg Matthes, Franziska Marquart, and Mira Mayrhofer. 2018. «Children's Attitudinal and Behavioral Reactions to Product Placements: Investigating the Role of Placement Frequency, Placement Integration, and Parental Mediation». International Journal of Advertising 37 (2): 236-55. https://doi.org/10.1080/02650487.2016.1218672.

Nairn, Agnes, and Cordelia Fine. 2008. «Who's Messing with My Mind? The Implications of DualProcess Models for the Ethics of Advertising to Children». International Journal of Advertising 27 (3): 447-70. https://doi.org/10.2501/S0265048708080062.

Nelson, Michelle R., Lucy Atkinson, Mark A. Rademacher, and Regina Ahn. 2017. «How Media and Family Build Children's Persuasion Knowledge». Journal of Current Issues and Research in Advertising 38 (2): 165-83. https://doi.org/10.1080/10641734.2017.1291383.

Pauw, Pieter De, Verolien Cauberghe, and Liselot Hudders. 2018. «Taking Children's Advertising Literacy to a Higher Level: A Multilevel Analysis Exploring the Influence of Parents, Peers, and Teachers». Communication Research 46 (8): 1197-1221. https://doi. org/10.1177/0093650218797876.

Pauw, Pieter De, Liselot Hudders, and Verolien Cauberghe. 2018. «Disclosing Brand Placement to Young Children». International Journal of Advertising 37 (4): 508-25. https://doi.org/10. 1080/02650487.2017.1335040.

Piaget, Jean. 1929. The Child's Conception of the World. London: Routledge \& Kegan.

Reijmersdal, Eva A. van, Sophie C. Boerman, Moniek Buijzen, and Esther Rozendaal. 2017. «This Is Advertising! Effects of Disclosing Television Brand Placement on Adolescents». Journal of Youth and Adolescence 46 (2): 328-42. https://doi.org/10.1007/s10964-016-0493-3.

van Reijmersdal, Eva A., and Sophia van Dam. 2020. «How Age and Disclosures of Sponsored Influencer Videos Affect Adolescents' Knowledge of Persuasion and Persuasion». Journal of Youth and Adolescence 49 (7): 1531-44. https://doi.org/10.1007/s10964-019-01191-z.

Reijmersdal, Eva A. van, Esther Rozendaal, and Moniek Buijzen. 2012. «Effects of Prominence, Involvement, and Persuasion Knowledge on Children's Cognitive and Affective Responses to Advergames». Journal of Interactive Marketing 26 (1): 33-42. https://doi.org/10.1016/j. intmar.2011.04.005. 
Reijmersdal, Eva A. van, Esther Rozendaal, Liselot Hudders, Ini Vanwesenbeeck, Veroline Cauberghe, and Zeph M.C. van Berlo. 2020. «Effects of Disclosing Influencer Marketing in Videos: An Eye Tracking Study among Children in Early Adolescence». Journal of Interactive Marketing 49: 94-106. https://doi.org/10.1016/j.intmar.2019.09.001.

Rideout, Victoria. 2014. "Advertising to Children and Teens: Current Practices». Common Sense Media. https://www.commonsensemedia.org/file/csm-advertisingresearchbrief20141pdf/download.

Rozendaal, Esther, Laura Buijs, and Eva A. van Reijmersdal. 2016. "Strengthening Children's Advertising Defenses: The Effects of Forewarning of Commercial and Manipulative Intent». Frontiers in Psychology 7: 1-11. https://doi.org/10.3389/fpsyg.2016.01186.

Rozendaal, Esther, Matthew A. Lapierre, Eva A. van Reijmersdal, and Moniek Buijzen. 2011. «Reconsidering Advertising Literacy as a Defense Against Advertising Effects». Media Psychology 14 (4): 333-54. https://doi.org/10.1080/15213269.2011.620540.

Spielvogel, Ines, Brigitte Naderer, and Jörg Matthes. 2020. «Again and Again: Exploring the Influence of Disclosure Repetition on Children's Cognitive Processing of Product Placement». International Journal of Advertising 39 (5): 611-30. https://doi.org/10.1080/02650487.2019 .1648984 .

Spielvogel, Ines, Brigitte Naderer, and Jörg Matthes. 2021. «Disclosing Product Placement in Audiovisual Media Services: A Practical and Scientific Perspective on the Implementation of Disclosures across the European Union». International Journal of Advertising 40 (1): 5-25. https://doi.org/10.1080/02650487.2020.1781478.

Terlutter, Ralf, and Julia Spielvogel. 2010. «Einflussfaktoren auf die Entwicklung der Werbekompetenz bei Kindern». Der Markt 49 (1): 17-41. https://doi.org/10.1007/s12642-0100022-y.

Uribe, Rodrigo, and Alejandra Fuentes-García. 2020. «Disclosing Product Placements of Fast Food to Children: The Importance of Reinforcing the Use of Disclosures and the Age of Children». Health Communication 35 (11): 1415-25. https://doi.org/10.1080/10410236.20 19.1636344.

Vanwesenbeeck, Ini, Koen Ponnet, and Michel Walrave. 2016. «Go with the Flow: How Children's Persuasion Knowledge Is Associated with Their State of Flow and Emotions during Advergame Play». Journal of Consumer Behaviour 15: 38-47. https://doi.org/10.1002/cb.1529.

Verhellen, Yann, Caroline Oates, Patrick De Pelsmacker, and Nathalie Dens. 2014. "Children's Responses to Traditional versus Hybrid Advertising Formats: The Moderating Role of Persuasion Knowledge». Journal of Consumer Policy 37 (2): 235-55. https://doi.org/10.1007/ s10603-014-9257-1.

Wright, Peter, Marian Friestad, and David M. Boush. 2005. «The Development of Marketplace Persuasion Knowledge in Children, Adolescents, and Young Adults». Journal of Public Policy \& Marketing 24 (2): 222-33. https://doi.org/10.1509/jppm.2005.24.2.222. 
Zarouali, Brahim, Pieter De Pauw, Koen Ponnet, Michel Walrave, Karolien Poels, Verolien Cauberghe, and Liselot Hudders. 2019a. «Considering Children's Advertising Literacy from a Methodological Point of View: Past Practices and Future Recommendations». Journal of Current Issues and Research in Advertising 40 (2): 196-213. https://doi.org/10.1080/106417 34.2018.1503109.

Zarouali, Brahim, Michel Walrave, Koen Ponnet, and Karolien Poels. 2019b. "Advertising Literacy». In The International Encyclopedia of Media Literacy, 1-11. https://doi. org/10.1002/9781118978238.ieml0006.

\section{Sampled Studies}

[1] An, Soontae, and Susannah Stern. 2011. «Mitigating the Effects of Advergames on Children». Journal of Advertising 40 (1): 43-56. https://doi.org/10.2753/JOA0091-3367400103.

[2] Boerman, Sophie C., and Eva A. van Reijmersdal. 2020. «Disclosing Influencer Marketing on YouTube to Children: The Moderating Role of Para-Social Relationship». Frontiers in Psychology 10 (January): 3042. https://doi.org/10.3389/fpsyg.2019.03042.

[3] Coates, Anna Elizabeth, Charlotte Alice Hardman, Jason Christian Grovenor Halford, Paul Christiansen, and Emma Jane Boyland. 2019. «The Effect of Influencer Marketing of Food and a "Protective" Advertising Disclosure on Children's Food Intake». Pediatric Obesity 14 (10). https://doi.org/10.1111/ijpo.12540.

[4] Daems, Kristien, Freya De Keyzer, Patrick De Pelsmacker, and Ingrid Moons. 2019. «Personalized and Cued Advertising Aimed at Children». Young Consumers 20 (2). https://doi. org/10.1108/YC-10-2018-0864.

[5] De Jans, Steffi, Veroline Cauberghe, and Liselot Hudders. 2018. «How an Advertising Disclosure Alerts Young Adolescents to Sponsored Vlogs: The Moderating Role of a PeerBased Advertising Literacy Intervention through an Informational Vlog». Journal of Advertising 47 (4): 309-25. https://doi.org/10.1080/00913367.2018.1539363.

[6] De Jans, Steffi, and Liselot Hudders. 2020. «Disclosure of Vlog Advertising Targeted to Children». Journal of Interactive Marketing 52 (November): 1-19. https://doi.org/10.1016/j. intmar.2020.03.003.

[7] De Jans, Steffi, Ini Vanwesenbeeck, Veroline Cauberghe, Liselot Hudders, Esther Rozendaal, and Eva A. van Reijmersdal. 2018. «The Development and Testing of a Child-Inspired Advertising Disclosure to Alert Children to Digital and Embedded Advertising». Journal of Advertising 47 (3): 255-69. https://doi.org/10.1080/00913367.2018.1463580.

[8] De Pauw, Pieter, Liselot Hudders, and Verolien Cauberghe. 2018. «Disclosing Brand Placement to Young Children». International Journal of Advertising 37 (4): 508-25. https://doi.or g/10.1080/02650487.2017.1335040.

[9] Folkvord, Frans, Francisco Lupiáñez-Villanueva, Cristiano Codagnone, Francesco Bogliacino, Giuseppe Veltri, and George Gaskell. 2017. «Does a "Protective" Message Reduce the Impact of an Advergame Promoting Unhealthy Foods to Children? An Experimental Study in Spain and The Netherlands». Appetite 112 (May): 117-23. https://doi.org/10.1016/j.appet.2017.01.026. 
[10] Hoek, Rhianne W., Esther Rozendaal, Hein T. van Schie, Eva A. van Reijmersdal, and Moniek Buijzen. 2020. «Testing the Effectiveness of a Disclosure in Activating Children's Advertising Literacy in the Context of Embedded Advertising in Vlogs». Frontiers in Psychology 11. https://doi.org/10.3389/fpsyg.2020.00451.

[11] Lacoste-Badie, S., M. Minvielle, and O. Droulers. 2019. «Attention to Food Health Warnings in Children's Advertising: A French Perspective». Public Health 173 (August): 69-74. https://doi.org/10.1016/j.puhe.2019.05.012.

[12] Panic, Katarina, Verolien Cauberghe, and Patrick De Pelsmacker. 2013. «Comparing TV Ads and Advergames Targeting Children: The Impact of Persuasion Knowledge on Behavioral Responses». Journal of Advertising 42 (2-3): 264-73. https://doi.org/10.1080/00913367.20 13.774605 .

[13] Rozendaal, Esther, Laura Buijs, and Eva A. van Reijmersdal. 2016. «Strengthening Children's Advertising Defenses: The Effects of Forewarning of Commercial and Manipulative Intent». Frontiers in Psychology 7. https://doi.org/10.3389/fpsyg.2016.01186.

[14] Spielvogel, Ines, Brigitte Naderer, and Jörg Matthes. 2020. «Again and Again: Exploring the Influence of Disclosure Repetition on Children's Cognitive Processing of Product Placement». International Journal of Advertising 39 (5): 611-30. https://doi.org/10.1080/02650 487.2019.1648984.

[15] Uribe, Rodrigo, and Alejandra Fuentes-García. 2020. «Disclosing Product Placements of Fast Food to Children: The Importance of Reinforcing the Use of Disclosures and the Age of Children». Health Communication 35 (11): 1415-25. https://doi.org/10.1080/10410236. 2019.1636344.

[16] van Reijmersdal, Eva A., Sophie C. Boerman, Moniek Buijzen, and Esther Rozendaal. 2017. «This Is Advertising! Effects of Disclosing Television Brand Placement on Adolescents». Journal of Youth and Adolescence 46 (2): 328-42. https://doi.org/10.1007/s10964-0160493-3.

[17] van Reijmersdal, Eva A., Esther Rozendaal, Liselot Hudders, Ini Vanwesenbeeck, Veroline Cauberghe, and Zeph M. C. van Berlo. 2020. «Effects of Disclosing Influencer Marketing in Videos: An Eye Tracking Study Among Children in Early Adolescence». Journal of Interactive Marketing 49 (February): 94-106. https://doi.org/10.1016/j.intmar.2019.09.001.

[18] van Reijmersdal, Eva A., and Sophia van Dam. 2020. «How Age and Disclosures of Sponsored Influencer Videos Affect Adolescents' Knowledge of Persuasion and Persuasion». Journal of Youth and Adolescence 49 (7): 1531-44. https://doi.org/10.1007/s10964-019-01191-z.

[19] Vanwesenbeeck, Ini, Suzanna J. Opree, and Tim Smits. 2017. «Can Disclosures Aid Children's Recognition of TV and Website Advertising?». In Advances in Advertising Research VIII: Challenges in an Age of Dis-Engagement, edited by Vesna Zabkar and Martin Eisend, 45-57. European Advertising Academy. Wiesbaden: Springer Fachmedien. https:// doi.org/10.1007/978-3-658-18731-6_4. 